\title{
Assessing cultivated cropland inherent vulnerability to sediment and nutrient losses with the Soil Vulnerability Index
}

\author{
Claire Baffaut, Allen L. Thompson, Lisa F. Duriancik, Kevin A. Ingram, and M. Lee Norfleet
}

\section{GOAL AND PURPOSE OF THE SOIL VULNERABILITY INDEX}

The National Assessment for Cropland (Conservation Effects Assessment Project [CEAP] Cropland) intends to report the effects of conservation practices applied to cropland with respect to societal benefits, such as cleaner water and soil quality improvements that will result in more sustainable and profitable production over time. One outcome of CEAP is the need for a consistent approach to assessing where conservation systems would be beneficial so that the USDA Natural Resources Conservation Service (NRCS) and other conservation managers can target efforts to those areas. This approach requires the development of tools to assess cropland soil vulnerability to cultivation. Soil vulnerability describes the ability of soil resources to withstand potentially hazardous impacts of cultivation that allow losses of sediment or excess nutrients from the farmer's field into surface and ground waters. Such losses can lead to reduction in surface and ground water quality in agroecosystems. The Soil Vulnerability Index (SVI) was developed to rank a soil for vulnerability to loss of sediment and/ or excess nutrients from cultivation. Such ranking will increase the speed of interpretation for conservation planning and allow planners and resource managers to

Claire Baffaut is a research hydrologist at the USDA Agricultural Research Service Cropping Systems and Water Quality Research Unit, Columbia, Missouri. Allen L. Thompson is a professor in the Department of Biomedical, Biological, and Chemical Engineering, University of Missouri, Columbia, Missouri. Lisa F. Duriancik is the leader for the Conservation Effects Assessment Project (CEAP) Watershed Assessment Studies Component at the USDA Natural Resources Conservation Service (NRCS) Resource Inventory and Assessment Division, Beltsville, Maryland. Kevin A. Ingram is the leader for the CEAP Natural Resources Analysis Team at the USDA NRCS Resource Inventory and Assessment Division, Beltsville, Maryland. M. Lee Norfleet is the leader for the CEAP Modeling Team at the USDA NRCS Resource Inventory and Assessment Division, Temple, Texas. more efficiently assess a field's needs and to narrow the suite of conservation solutions viable for meeting resource concerns.

Guiding Principles. Three general principles guided the design and development of the SVI:

1. Conservation managers, producers, and the public should easily be able to understand the meaning of the SVI. NRCS designed the SVI as a categorical index that classifies vulnerability into four categories from low to very high.

2. The SVI should be regionally relevant, meaning that within a specific region, cropland areas with a lower vulnerability experienced less sediment and nutrient losses than cropland with a greater vulnerability. A region was defined as an area equivalent in size to a hydrologic unit of level two (HUC2), i.e., the drainage area of a major river (e.g., the Missouri River) or a water body (e.g., the Chesapeake Bay region or the Great Lakes region).

3. The SVI should be based on soil behavior without any conservation or management consideration. Nutrient and sediment losses from cropland were assessed for a no-conservation practice scenario, which included nonconservation tillage, preventive pesticide applications, and uniform fertilization at rates that exceed crop removal (Thompson et al. 2020).

With these three guiding principles in mind, NRCS used the results of Agricultural Policy/Environmental eXtender model (APEX) simulations conducted during the Cropland CEAP assessment in the Upper Mississippi, Tennessee, and Ohio River basins (USDA NRCS 2012) to select the variables that drive the SVI and develop vulnerability classes based on those variables. Even though the guiding principles precluded management from affecting the SVI, the leaching component ultimately included consideration for artificial drainage because it significantly affects the subsurface movement of water and associated loss of dissolved constituents. Application and evaluation of the SVI in several USDA landscape-scale water quality initiatives and feedback from watershed resource managers led to the development of new versions of the SVI: the Soil Vulnerability Index for Cultivated Cropland (SVI-cc [USDA NRCS 2018]) and the Soil Vulnerability Index for Cultivated Cropland 2 (SVI-cc2 [USDA NRCS 2019]). In addition to reviews and evaluations by NRCS soil scientists, an independent review of the 2012 SVI version-presented in the Upper Mississippi Cropland CEAP report (USDA NRCS 2012)—started in 2012, first in the Goodwater Creek Experimental Watershed (Chan et al. 2017), and then later across 13 CEAP watersheds. These watersheds were selected among the 23 watersheds of the CEAP Watershed Assessment Studies, based on percentage of cropland and the range of precipitation and physiographic characteristics. This evaluation across multiple regions resulted in a special collection of papers presented in this issue of the Journal of Soil and Water Conservation. Among those, Thompson et al. (2020) include a presentation of the methods used to develop the SVI, a definition of the SVI evaluated in this special collection, and a synthesis of the strengths and limitations of the index. Table 1 provides an overview of the development and review of the SVI.

USES OF THE SOIL VULNERABILITY INDEX The SVI helped assess land resources during previous landscape-scale water quality initiatives. As early as 2009, SVI maps in combination with model results helped identify the most vulnerable cropland. When combined with spatial information about conservation practices already implemented, these results helped inform the need for additional conservation practices (USDA NRCS 2011). These assessments can help NRCS, states, or other local agencies complete needed resource assessments at field, landscape, or watershed scale, at the planning or evaluation stage. 


\section{Table 1}

History of the Soil Vulnerability Index development and review.

\begin{tabular}{|c|c|c|}
\hline Date & Development/evaluation phase & Product \\
\hline 2009 to 2012 & $\begin{array}{l}\text { Development of the SVI from Conservation Effects Assessment Project (CEAP) cropland } \\
\text { component study results }\end{array}$ & USDA NRCS 2012 \\
\hline 2012 to 2018 & Development of the Soil Vulnerability Index for Cultivated Cropland (SVI-cc) & USDA NRCS 2018 \\
\hline 2012 to 2015 & $\begin{array}{l}\text { CEAP Croplands Watersheds Studies: Testing of Targeting Tools in Goodwater Creek } \\
\text { Experimental Watershed, Missouri }\end{array}$ & Chan et al. 2017 \\
\hline 2015 to 2018 & $\begin{array}{l}\text { CEAP Watershed Assessment Study and National Soil Survey Center Joint Multi-Location } \\
\text { Project: Evaluation and Improvement of the USDA Natural Resources Conservation Service } \\
\text { (NRCS) Soil Vulnerability Index }\end{array}$ & $\begin{array}{l}\text { Lee et al. } 2018 \\
\text { Journal of Soil and Water } \\
\text { Conservation } 2020 \text { special section }\end{array}$ \\
\hline 2018 & NRCS internal review & USDA NRCS 2019 \\
\hline
\end{tabular}

In Tennessee, the SVI helped assess the extent to which erosion from agricultural land can affect stream and river water quality in the different regions of the Tennessee River basin (University of Maryland Center for Environmental Science, Integration and Application Network 2018a). The SVI was calculated, reclassified by calculating the percentage of high vulnerability cropland in each hydrologic unit of level twelve (HUC12), and rescaled by calculating the Z-score to classify each HUC12 in one of five possible vulnerability categories (University of Maryland Center for Environmental Science, Integration and Application Network 2018b). This reclassification was necessary to be consistent with the other resource vulnerability assessments conducted in the river basin.

For future evaluations and conservation planning, the new NRCS Conservation Assessment and Ranking Tool (CART), designed to streamline the assessment of conservation needs and delivery of conservation services, uses the SVI as an underlying layer for cultivated croplands. The SVI is used as part of the site risk assessment aspect of this new NRCS tool. It is also used as one of the data sources to inform the conservation planning thresholds aspect of CART.

\section{INTRODUCTION AND SUMMARY OF THIS SPECIAL COLLECTION}

The collection of papers included in this special journal issue evaluates the SVI presented in the Upper Mississippi Cropland CEAP report (USDA NRCS 2012). This version had two compo- nents: a runoff component that assessed the risks of sediment and nutrient loss by surface runoff, and a leaching component that addressed the risks of nutrient loss by leaching. Adjustments increased the risk by leaching when artificial drainage is present and for high rock fragment content. Thompson et al. (2020) discuss the development of this version of the SVI and synthesize the results of the four studies that evaluated the index in 13 watersheds that cover a range of climate, soils, topography, cropping systems, and cropland management including with or without artificial drainage, and with or without irrigation. The four papers that are the basis for this synthesis focus on a range of aspects. Lohani et al. (2020a) analyze SVI usefulness as a function of the range of slopes in a watershed. Baffaut et al. (2020) evaluate SVI rankings when cropland is artificially drained, whether by surface ditches or by subsurface tiles. Yasarer et al. (2020) evaluate the SVI in two Mississippi watersheds. Finally, Lohani et al. (2020b) assess whether SVI distribution on cropland in various watersheds helped explain sediment and nutrient loads exported from these watersheds. Findings define the conditions under which the SVI provided useful results that agreed with expert consensus, as well as the shortcomings associated with specific conditions, and possible improvements.

Because of NRCS's own internal reviews of the SVI, NRCS concurrently identified some of the SVI shortcomings presented in this special collection and addressed them in the SVI-cc and in the SVI-cc2. For example, the SVI-cc and the SVI-cc2 consider the handling of complex soils in the SVI (Thompson et al. 2020; Baffaut et al. 2020) by calculating the SVI for each of the components, including the dominant and the minor ones in the mapping unit (USDA NRCS 2018, 2019). Similarly, the SVI-cc and the SVI-cc2 address the absence of differentiation between leaching caused by artificial drainage and that caused by high soil permeability. Both indices subdivide the SVI leaching component into two components: the leaching component, which is equivalent to the SVI undrained leaching component without considering the presence of artificial drainage, and a second leaching component, which considers the presence of artificial drainage (USDA NRCS 2018). The SVI-cc names the second leaching component the SVI "managed leaching" component (USDA NRCS 2018) while the SVI-cc2 names it the SVI "drained leaching" component (USDA NRCS 2019).

For other shortcomings, research is continuing using data from CEAP watershed studies to find appropriate modifications of the SVI that will address some of the limitations identified and presented in this special collection. For example, the SVI seemed to underestimate the vulnerability to runoff for shallow top soils above a restrictive layer or in regions with very high intensity rainfall. So goes the process of tool development: development; testing and evaluation; identification of limitations; and repeat as appropriate, with the goal to improve sustainable environmental quality. 


\section{REFERENCES}

Baffaut, C., S. Lohani, A.L. Thompson, A.R. Davis, N. Aryal, D.L. Bjorneberg, R.L. Bingner, S.M. Dabney, L.F. Duriancik, D.E. James, K.W. King, S. Lee, G.W. McCarty, L.A. Pease, M.L. Reba, A.M. Sadeghi, M.D.Tomer, M.R.Williams, and L.M.W. Yasarer. 2020. Evaluation of the Soil Vulnerability Index for artificially drained cropland across eight Conservation Effects Assessment Project watersheds. Journal of Soil and Water Conservation 75(1):28-41, doi:10.2489/jswc.75.1.28.

Chan, R., C. Baffaut, A.L.Thompson, and E.J. Sadler. 2017.Validating the Soil Vulnerability Index for a claypan watershed. Catena 148:185-194.

Lee, S., A.M. Sadeghi, G.W. McCarty, C. Baffaut, S. Lohani, L.F. Duriancik, A.L. Thompson, I-Y.Yeo, and C. Wallace. 2018. Assessing the suitability of the Soil Vulnerability Index (SVI) on identifying croplands vulnerable to nitrogen loss using the SWAT model. Catena 167:1-12.

Lohani, S., C. Baffaut, A.L. Thompson, N. Aryal, R.L. Bingner, D.L. Bjorneberg, D.D. Bosch, R.B. Bryant, A. Buda, S.M. Dabney, A.R. Davis, L.F. Duriancik, D.E. James, K.W. King, P.J.A. Kleinman, M. Locke, G.W. McCarty, L.A. Pease, M.L. Reba, D.R. Smith, M.D. Tomer, T.L. Veith, M.R. Williams, and L.M.W. Yasarer. 2020a. Performance of the Soil Vulnerability Index with respect to slope, digital elevation model resolution, and hydrologic soil group. Journal Soil and Water Conservation 75(1):12-27, doi:10.2489/ jswc.75.1.12.

Lohani, S., C. Baffaut, A.L. Thompson, and E.J. Sadler. 2020b. Soil Vulnerability Index assessment as a tool to explain annual constituent loads in a nested watershed. Journal of Soil and Water Conservation 75(1):42-52, doi:10.2489/ jswc.75.1.42.

Thompson, A.L., C. Baffaut, S. Lohani, L.F. Duriancik, M.L. Norfleet, and K. Ingram. 2020. Purpose, development, and synthesis of the Soil Vulnerability Index for inherent vulnerability classification of cropland soils. Journal Soil and Water Conservation 75(1):1-11, doi:10.2489/ jswc.75.1.1.

University of Maryland Center for Environmental Science, Integration and Application Network. 2018a. A Report Card for the Tennessee River Basin. Cambridge, MD: University of Maryland Center for Environmental Science.

University of Maryland Center for Environmental Science, Integration and Application Network. 2018b. Tennessee River Basin Report Card: Methods report on data sources, calculation, and additional discussion. Cambridge, MD: University of Maryland Center for Environmental Science.

USDA NRCS (Natural Resources Conservation Service). 2011. Assessment of the effects of conservation practices on cultivated cropland in the Chesapeake Bay Region. February 2011. Washington, DC: USDA Natural Resources Conservation Service, Conservation Effects Assessment Project. http://www.nrcs.usda. gov/Internet/FSE_DOCUMENTS/stelprdb1042076.pdf.

USDA NRCS. 2012. Assessment of the effects of conservation practices on cultivated cropland in the Upper Mississippi River Basin. July 2012. Washington, DC: USDA Natural Resources Conservation Service, Conservation Effects Assessment Project. https://www.nrcs. usda.gov/Internet/FSE_DOCUMENTS/stelprdb1042093.pdf.

USDA NRCS. 2018. CEAP (Conservation Effects Assessment Project) Soil Vulnerability Index for Cultivated Cropland (SVI-cc) User Guide. Version 1.12. June 2018. Washington, DC: USDA Natural Resources Conservation Service.

USDA NRCS. 2019. CEAP (Conservation Effects Assessment Project) Soil Vulnerability Index for Cultivated Cropland (SVI-cc) User Guide. Version 2.0. September 2019. Washington, DC: USDA Natural Resources Conservation Service.

Yasarer, L.M.W., S. Lohani, R.L. Bingner, M.A. Locke, C. Baffaut, and A.L. Thompson. 2020. Assessment of the Soil Vulnerability Index and comparison with AnnAGNPS in two Lower Mississippi River Basin watersheds. Journal of Soil and Water Conservation 75(1): 53-61, doi:10.2489/ jswc.75.1.53. 